\title{
Pengaruh Lingkungan Kerja dan Kompensasi Terhadap Kinerja Karyawan pada PT. Sukses Expamet
}

\section{Effect on The Work Environment and Compensation on Employee Performance in. PT. Expamet Success}

\author{
Endang Sugiarti \\ Universitas Pamulang, Indonesia \\ Diterima: 16 September 2020; Disetujui: 26 September 2020; Dipublish: 17 Oktober 2020 \\ *Coresponding Email: dosen00725@unpam.ac.id
}

\begin{abstract}
Abstrak
Penelitian ini bertujuan untuk mengetahui pengaruh lingkungan kerja dan kompensasi terhadap kinerja karyawan pada PT. Sukses Expamet. Metode yang digunakan adalah explanatory research dengan teknik analisis menggunakan analisis statistik dengan pengujian regresi, korelasi, determinasi dan uji hipotesis. Hasil penelitian ini lingkungan kerja berpengaruh signifikan terhadap kinerja karyawan sebesar 53,6\%, uji hipotesis diperoleh $t$ hitung $>t$ tabel atau $(7,815>2,006)$. Kompensasi berpengaruh signifikan terhadap kinerja karyawan sebesar 43,3\%, uji hipotesis diperoleh $t$ hitung $>t$ tabel atau $(6,358>2,006)$. Lingkungan kerja dan kompensasi secara simultan berpengaruh signifikan terhadap kinerja karyawan dengan persamaan regresi $Y=8,506+0,426 \mathrm{X} 1+0,366 \mathrm{X} 2$ dan kontribusi pengaruh sebesar 62,4\%, uji hipotesis diperoleh $\mathrm{F}$ hitung $>\mathrm{F}$ tabel atau $(43,076>2,780)$.
\end{abstract}

Kata Kunci: Lingkungan kerja, Kompensasi, Kinerja Karyawan.

\begin{abstract}
This study aims to determine the effect of work environment and compensation on employee performance at PT. Expamet success. The method used is explanatory research with analysis techniques using statistical analysis with regression testing, correlation, determination and hypothesis testing. The results of this study, the work environment has a significant effect on employee performance by 53.6\%, hypothesis testing obtained $t$ count $>t$ table or $(7,815>2,006)$. Compensation has a significant effect on employee performance by 43.3\%, hypothesis testing is obtained $t$ count> $t$ table or (6.358> 2.006). Work environment and compensation simultaneously have a significant effect on employee performance with the regression equation $Y=8.506+0.426 X 1+0.366 X 2$ and the contribution of the effect is $62.4 \%$, the hypothesis test is obtained $F$ count> $F$ table or (43.076> 2.780).
\end{abstract}

Keywords: work environment, compensation, employee performance.

How to Cite: Sugiarti, E. (2020). Pengaruh Lingkungan Kerja dan Kompensasi Terhadap Kinerja Karyawan Pada PT. Sukses Expamet. Journal of Education, Humaniora and Social Sciences (JEHSS). 3(2): 479-486. 


\section{PENDAHULUAN}

Kesiapan dan pengelolaan sumber daya yang tepat akan memiliki nilai yang lebih ketika kondisi sangat membutuhkan. Terlebih melihat kenyataan sekarang ini dengan telah diberlakukannya perdagangan bebas semua pelaku bisnis tidak terkecuali PT. Sukses Expamet. terus memperkuat pangsa pasar dalam negeri sebagai salah satu langkah menghadapi persaingan dalam Masyarakat Ekonomi ASEAN (MEA). Hal itu karena kuatnya pertumbuhan sektor bisnis retail didalam negeri dan besarnya potensi pertumbuhan pasar dimasa yang akan datang.

PT. Sukses Expamet berdiri tahun 1988 di Surabaya- Indonesia. Dalam perkembangannya selama lebih dari 20 tahun telah menjadi salah satu produsen expanded metal dengan merk JILU mesh yang tersebar di Indonesia dan terus berkembang dengan memproduksi bahan bangunan lainnya. Sebagi pemimpin pasar, PT. Sukses Expamet menetapkan standart yang tinggi untuk waktu produksi, tingkat kepuasan pelanggan, dan kualitas demi menjaga kepercayaan pasar.

Kinerja dapat dinilai dari semangat kerja karyawannya. Salah satu pendorong optimalnya kinerja adalah pemberian kompensasi yang sesuai dari kinerja yang dihasilkan dalam menyelesaikan tugas karyawan tersebut. Dalam pelaksanaan tugas sehari-hari kekompensasian sering menjadi kendala dalam sebuah organisasi, rendahnya kekompensasian menjadi persoalan yang berulang-ulang terjadi, dan jelas hal tersebut jika dibiarkan akan menjadi persoalan yang rumit yang akan memiliki dampak pada integritas dan kinerja secara organisasi secara keseluruhan.

Dari hasil prariset yang penulis lakukan, berikut ini ketimpangan yang terjadi dimana disaat perusahaan sedang menggalakkan program kinerja yang berdayaguna namun justru pada perusahaan ini kompensasi kerja menunjukkan trend yang kurang baik, kinerja yang optimal yang dapat memenuhi akseptasi perusahaan belum dijalankan sebagaimana mestinya, misalnya datang terlambat, sering meninggalkan pekerjaan sebelum pada waktunya dan lain-lain. Sumber daya manusia juga memiliki posisi sangat strategis dalam organisasi, artinya unsur manusia memegang peranan penting dalam melakukan aktivitas untuk pencapaian tujuan.

Untuk itulah maka eksistensi sumber daya manusia dalam organisasi sangat kuat. Guna mencapai kondisi yang lebih baik, maka dituntut adanya Manajemen terhadap sumber daya manusia secara memadai sehingga terciptalah sumber daya manusia yang berkualitas, loyal dan berprestasi. Manajemen sumber daya manusia merupakan usaha untuk mengerahkan dan mengelola sumber daya manusia di dalam organisasi agar mampu berpikir dan bertindak sebagaimana yang diinginkan oleh organisasi.

Dorongan karyawan dalam menjalankan kewajibannya menjadi pertaruhan yang juga sangat penting dalam sebuah organisasi. Dorongan atau keinginan dalam diri pribadi karyawan menggambarkan adanya kemauan untuk bekerja dengan sungguh-sungguh. Apabila seseorang terlingkungan kerja, ia akan berusaha berbuat sekuat tenaga untuk mewujudkan apa yang diinginkannya. Namun belum tentu upaya yang keras itu akan menghasilkan kinerja yang diharapkan, apabila tidak disalurkan dalam arahan seorang pimpinan untuk mencapai tujuan organisasi Mora, Z., et al., 2020; Latief, et al., 2019; Latief, et al., 2019).

Oleh karena itu, upaya tersebut di atas diarahkan dan lebih konsisten dengan tujuan ke dalam sasaran organisasi. Organisasi juga dituntut mampu mengidentifikasikan kemauan para anggotanya yang menimbulkan kepuasan kerja melalui berbagai cara dengan memenuhi kebutuhan anggota organisasi, baik yang bersifat motivator sebagai faktor intrinsik maupun hygiene sebagai faktor ekstrinsik.

Lingkungan kerja bagi suatu perusahaan juga memiliki peranan yang penting dalam meningkatkan kinerja karyawannya. Bekerja di lingkungan yang nyaman seperti teman kerja yang siap untuk membantu dan berinteraksi satu sama lain saat bekerja bahkan pimpinan perusahaan memperlakukan semua karyawan sama sehingga dapat menghasilkan peningkatan kinerja karyawan serta kinerja seluruh organisasi. Dengan demikian hubungan baik antara kondisi lingkungan dengan kondisi karyawan mencerminkan pengendalian yang menciptakan 
antusiasme untuk bersatu dalam organisasi dalam mencapai tujuan (Latief, et al., 2018; Syardiansah, et al., 2020; Haryati, et al., 2019).

Kompensasi merupakan bagian dari kebijakan perusahaan dengan semua bentuk pembayaran yang dimaksudkan sebagai penghargaan balas jasa atas kinerja karyawan yang ditunjukkan oleh karyawan. Sebagai kunci pokok, sumber daya manusia dapat menentukan keberhasilan pelaksanaan kegiatan dalam perusahaan. Oleh karena itu berhasil tidaknya suatu organisasi atau institusi akan ditentukan oleh faktor manusianya atau karyawannya dalam mencapai tujuannya. Seorang karyawan yang memiliki kinerja yang tinggi dan baik dapat menunjang tercapainya tujuan dan sasaran yang telah ditetapkan oleh suatu organisasi. Semua karyawan disini adalah tenaga kerja yang bekerja dan menerima upah di dalam hubungan kerja dengan perusahaan dengan sumber daya manusia sebagai aset utama maka semua insan bank berusaha memiliki tanggung jawab dalam pencapaian pelaksanaan kebijakan yang ditetapkan. Kinerja karyawan dapat ditingkatkan melalui pemberian kompensasi yang sehingga karyawan memiliki kinerja yang tinggi dalam melaksanakan pekerjaan.

Kompensasi merupakan cara perusahaan dalam membantu karyawan yang bekerja di perusahaan demi meningkatkan standar hidup karyawan dan kebutuhan-kebutuhan setiap hari yang stiap tahunnya meningkat. Dengan adanya kompensasi yang di berikan perusahaan diharapkan kinerja dan kepuasan kerja karyawan meningkat.

Tujuan penetapan indikator kinerja utama di perusahaan diantaranya untuk memperoleh informasi kinerja yang penting dan diperlukan dalam menyelenggarakan manajemen kinerja secara baik; untuk memperoleh ukuran keberhasilan dari pencapaian suatu tujuan dan sasaran strategis yang digunakan untuk perbaikan kinerja dan peningkatan akuntabilitas kinerja dan melakukan evaluasi dari setiap indikator yang menjadi tolok ukur kinerjanya.

Peningkatan kinerja disamping harus timbul upaya dalam diri karyawan juga disisi lain harus ada suatu manajemen yang baik. Manajemen tersebut harus merupakan suatu siklus tahapan-tahapan perencanaan, pelaksanaan, pemantauan dan evaluasi. Hasil evaluasi kinerja menjadi feedback bagi tahapan perencanaan berikutnya.

Berdasarkan beberapa faktor yang dapat mempengaruhi kinerja karyawan, maka penulis tertarik untuk melakukan penelitian yang berjudul Pengaruh Lingkungan kerja dan Kompensasi Terhadap Kinerja Karyawan Pada PT. Sukses Expamet“.

\section{METODE PENELITIAN}

Pada pengujian ini digunakan untuk mengetahui skor minimum dan maksimum, mean score dan standar deviasi dari masing-masing variabel. Adapun hasilnya sebagai berikut:

\begin{tabular}{lllllll} 
& \multicolumn{5}{c}{ Tabel Hasil Analisis Descriptive Statistics } \\
& $\mathrm{N}$ & Minimum & Maximum & Mean & Std. Deviation \\
\hline Lingkungan kerja (Xı) & 55 & 30 & 48 & 37.11 & 4.512 \\
\hline Kompensasi (X2) & 55 & 28 & 48 & 37.44 & 3.568 \\
\hline Kinerja Karyawan (Y) & 55 & 32 & 48 & 38.02 & 3.634 \\
\hline Valid N (listwise) & 55 & & & & \\
\hline
\end{tabular}

Lingkungan kerja diperoleh varians minimum sebesar 30 dan varians maximum 48 dengan mean score sebesar 3,71 dengan standar deviasi 4,512.

Kompensasi diperoleh varians minimum sebesar 28 dan varians maximum 48 dengan mean score sebesar 3,74 dengan standar deviasi 3,568.

Kinerja karyawan diperoleh varians minimum sebesar 32 dan varians maximum 48 dengan mean score sebesar 3,80 dengan standar deviasi 3,634.

Pada analisis Verifikatif ini dimaksudkan untuk mengetahui pengaruh variabel independen terhadap variabel dependen. Adapun hasil pengujian sebagai berikut:

a. Analisis Regresi Linier Berganda 
Endang Sugiarti, Pengaruh Lingkungan Kerja dan Kompensasi Terhadap Kinerja Karyawan

Uji regresi ini dimaksudkan untuk mengetahui perubahan variabel dependen jika variabel independen mengalami perubahan. Adapun hasil pengujiannya sebagai berikut:

Tabel Hasil Pengujian Regresi Linier Berganda

Coefficients $^{\mathrm{a}}$

\begin{tabular}{|c|c|c|c|c|c|c|}
\hline \multirow{2}{*}{\multicolumn{2}{|c|}{ Model }} & \multicolumn{2}{|c|}{ Unstandardized Coefficients } & \multirow{2}{*}{$\begin{array}{l}\text { Standardized Coefficients } \\
\text { Beta }\end{array}$} & \multirow[b]{2}{*}{$\mathrm{t}$} & \multirow[b]{2}{*}{ Sig. } \\
\hline & & $\mathrm{B}$ & Std. Error & & & \\
\hline 1 & (Constant) & 8.506 & $3 \cdot 370$ & & 2.524 & .015 \\
\hline & Lingkungan kerja $\left(\mathrm{X}_{1}\right)$ & .426 & .083 & .529 & 5.135 & .000 \\
\hline & Kompensasi (X2) & .366 & .105 & .359 & 3.488 & .001 \\
\hline
\end{tabular}

a. Dependent Variable: Kinerja Karyawan (Y)

Berdasarkan hasil pengujian pada tabel di atas, diperoleh persamaan regresi $\mathrm{Y}=8,506+$ 0,426X1 + 0,366X2. Dari persamaan tersebut dijelaskan sebagai berikut:

1) Konstanta sebesar 8,506 diartikan jika lingkungan kerja dan kompensasi tidak ada, maka telah terdapat nilai kinerja karyawan sebesar 8,506 point.

2) Koefisien regresi lingkungan kerja sebesar 0,426, angka ini positif artinya setiap ada peningkatan lingkungan kerja sebesar 0,426 maka kinerja karyawan juga akan mengalami peningkatan sebesar 0,426 point.

3) Koefisien regresi kompensasi sebesar 0,366, angka ini positif artinya setiap ada peningkatan kompensasi sebesar 0,366 maka kinerja karyawan juga akan mengalami peningkatan sebesar 0,366 point.

Analisis koefisien korelasi dimaksudkan untuk mengetahui tingkt kekuatan hubungan dari variabel independen terhadap variabel dependen baik secara parsial maupun simultan. Adapun hasil pengujian sebagai berikut:

Tabel Hasil Pengujian Koefisien Korelasi Lingkungan kerja Terhadap Kinerja Karyawan. Correlations $^{\mathrm{b}}$

\begin{tabular}{|c|c|c|c|}
\hline & & Lingkungan kerja $\left(\mathrm{X}_{1}\right)$ & Kinerja Karyawan $(\mathrm{Y})$ \\
\hline \multirow[t]{2}{*}{ Lingkungan kerja $\left(\mathrm{X}_{\mathrm{I}}\right)$} & Pearson Correlation & 1 & $.732^{* \pi}$ \\
\hline & Sig. (2-tailed) & & .000 \\
\hline \multirow[t]{2}{*}{ Kinerja Karyawan (Y) } & Pearson Correlation & $.73^{* *}$ & 1 \\
\hline & Sig. (2-tailed) & .000 & \\
\hline
\end{tabular}

Berdasarkan hasil pengujian diperoleh nilai korelasi sebesar 0,732 artinya lingkungan kerja memiliki hubungan yang kuat terhadap kinerja karyawan.

Tabel Hasil Pengujian Koefisien Korelasi Kompensasi Terhadap Kinerja Karyawan. Correlations ${ }^{\mathrm{b}}$

Kompensasi (X2) Kinerja Karyawan (Y)

\begin{tabular}{llll}
\hline Kompensasi (X2) & Pearson Correlation & 1 & $.658^{* *}$ \\
\cline { 2 - 4 } & Sig. (2-tailed) & & .000 \\
\hline Kinerja Karyawan $(\mathrm{Y})$ & Pearson Correlation & $.658^{* *}$ & 1 \\
\cline { 2 - 4 } & Sig. (2-tailed) & .000 & \\
\hline
\end{tabular}

**. Correlation is significant at the o.o1 level (2-tailed).

b. Listwise $\mathrm{N}=86$

Berdasarkan hasil pengujian diperoleh nilai korelasi sebesar 0,658 artinya kompensasi memiliki hubungan yang kuat terhadap kinerja karyawan.

Tabel Hasil Pengujian Koefisien Korelasi Lingkungan kerja dan Kompensasi secara simultan Terhadap Kinerja Karyawan.

Model Summary

$\begin{array}{llll}\text { Model R } & \text { R Square } & \text { Adjusted R Square } & \text { Std. Error of the Estimate }\end{array}$

\begin{tabular}{lllll}
\hline 1 & $.790^{\mathrm{a}}$ & .624 & .609 & 2.272
\end{tabular}

a. Predictors: (Constant), Kompensasi (X2), Lingkungan kerja (X1)

http://mahesainstitute.web.id/ojs2/index.php/jehss 
Berdasarkan hasil pengujian diperoleh nilai korelasi sebesar 0,790 artinya lingkungan kerja dan kompensasi secara simultan memiliki hubungan yang kuat terhadap kinerja karyawan.

Analisis koefisien determinasi dimaksudkan untuk mengetahui besarnya persentase pengaruh dari variabel independen terhadap variabel dependen baik secara parsial maupun simultan. Adapun hasil pengujian sebagai berikut:

Tabel Hasil Pengujian Koefisien Determinasi Lingkungan kerja Terhadap Kinerja Karyawan. Model Summary

\begin{tabular}{ll|llll} 
Model & $\mathrm{R}$ & R Square & $\begin{array}{l}\text { Adjusted } \\
\text { Square }\end{array}$ & $\begin{array}{l}\text { RStd. Error of } \\
\text { Estimate }\end{array}$ \\
\hline 1 & $.732^{\mathrm{a}}$ & .536 & .527 & 2.500 & \\
\hline
\end{tabular}

a. Predictors: (Constant), Lingkungan kerja (X1)

Berdasarkan hasil pengujian diperoleh nilai determinasi sebesar 0,536 artinya lingkungan kerja memiliki kontribusi pengaruh sebesar 53,6\% terhadap kinerja karyawan.

Tabel 7. Hasil Pengujian Koefisien Determinasi Kompensasi Terhadap Kinerja Karyawan. Model Summary

\begin{tabular}{lllll} 
Model & $\mathrm{R}$ & R Square & Adjusted R Square & Std. Error of the Estimate \\
\hline $\mathbf{1}$ & $.658^{\mathrm{a}}$ & .433 & .422 & 2.762 \\
\hline
\end{tabular}

a. Predictors: (Constant), Kompensasi $\left(\mathrm{X}_{2}\right)$

Berdasarkan hasil pengujian diperoleh nilai determinasi sebesar 0,433 artinya kompensasi memiliki kontribusi pengaruh sebesar $43,3 \%$ terhadap kinerja karyawan.

Tabel Hasil Pengujian Koefisien Determinasi Lingkungan kerja dan Kompensasi Terhadap Kinerja Karyawan.

Model Summary

\begin{tabular}{lllll} 
Model & $\mathrm{R}$ & R Square & Adjusted R Square & Std. Error of the Estimate \\
\hline 1 & $.790^{\mathrm{a}}$ & .624 & .609 & 2.272 \\
\hline
\end{tabular}

a. Predictors: (Constant), Kompensasi (X2), Lingkungan kerja ( $\left.\mathrm{X}_{1}\right)$

Berdasarkan hasil pengujian diperoleh nilai determinasi sebesar 0,624 artinya lingkungan kerja dan kompensasi secara simultan memiliki kontribusi pengaruh sebesar 62,4\% terhadap kinerja karyawan, sedangkan sisanya sebesar 37,6\% dipengaruhi faktor lain.

Pengujian Uji hipotesis Parsial (Uji t) digunakan untuk mengetahui hipotesis parsial mana yang diterima.

Hipotesis pertama: Terdapat pengaruh yang signifikan antara lingkungan kerja terhadap kinerja karyawan.

Coefficients $^{\mathrm{a}}$

Tabel Hasil Uji Hipotesis Lingkungan kerja Terhadap Kinerja Karyawan.

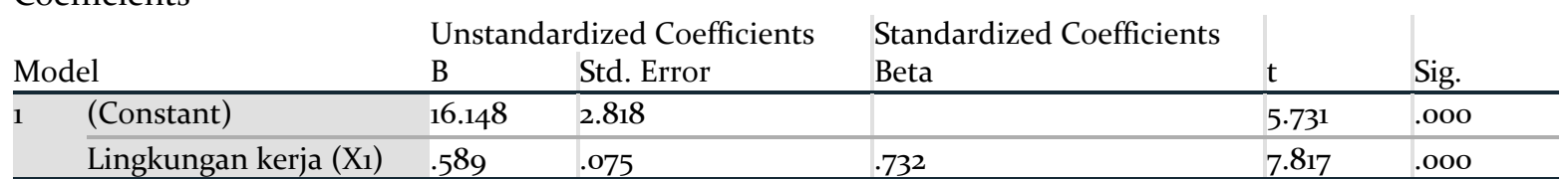

a. Dependent Variable: Kinerja Karyawan (Y)

Berdasarkan hasil pengujian pada tabel di atas, diperoleh nilai thitung $>\mathrm{t}$ tabel atau $(7,815$ $>2,006)$, dengan demikian hipotesis pertama yang diajukan bahwa terdapat pengaruh yang signifikan atara lingkungan kerja terhadap kinerja karyawan diterima.

Tabel Hasil Uji Hipotesis Kompensasi Terhadap Kinerja Karyawan.

$$
\text { Coefficients }^{\mathrm{a}}
$$

Model Unstandardized Coefficients Standardized Coefficients 
Endang Sugiarti, Pengaruh Lingkungan Kerja dan Kompensasi Terhadap Kinerja Karyawan

\begin{tabular}{llllllll} 
& & B & Std. Error & Beta & & \\
\hline 1 & (Constant) & 12.940 & 3.962 & & 3.266 & .002 \\
\cline { 2 - 7 } & Kompensasi (X2) & .670 & .105 & .658 & 6.358 & .000 \\
\hline
\end{tabular}

a. Dependent Variable: Kinerja Karyawan (Y)

Berdasarkan hasil pengujian pada tabel di atas, diperoleh nilai t hitung $>t$ tabel atau 66,358 $>2,006)$, dengan demikian hipotesis kedua yang diajukan bahwa terdapat pengaruh yang signifikan atara kompensasi terhadap kinerja karyawan diterima.

Pengujian hipotesis dengan uji $\mathrm{F}$ digunakan untuk mengetahui hipotesis simultan yang mana yang diterima.

Hipotesis ketiga Terdapat pengaruh yang signifikan antara lingkungan kerja dan kompensasi terhadap kinerja karyawan.

Tabel Hasil Uji Hipotesis Lingkungan kerja dan Kompensasi Terhadap Kinerja Karyawan. ANOVA $^{\mathrm{a}}$

\begin{tabular}{|c|c|c|c|c|c|c|}
\hline Model & & Sum of Squares & $\mathrm{df}$ & Mean Square & $\mathrm{F}$ & Sig. \\
\hline \multirow[t]{3}{*}{1} & Regression & 444.616 & 2 & 222.308 & 43.076 & $.000^{b}$ \\
\hline & Residual & 268.366 & 52 & 5.161 & & \\
\hline & Total & 712.982 & 54 & & & \\
\hline
\end{tabular}

Berdasarkan hasil pengujian pada tabel di atas, diperoleh nilai $\mathrm{F}$ hitung $>\mathrm{F}$ tabel atau $(43,076>2,780)$, dengan demikian hipotesis ketiga yang diajukan bahwa terdapat pengaruh yang signifikan atara lingkungan kerja dan kompensasi terhadap kinerja karyawan diterima.

\section{HASIL DAN PEMBAHASAN}

Pengaruh Lingkungan kerja Terhadap Kinerja Karyawan. Lingkungan kerja berpengaruh signifikan terhadap kinerja karyawan dengan korelasi sebesar 0,732 atau memiliki hubungan yang kuat dengan kontribusi pengaruh sebesar 53,6\%. Pengujian hipotesis diperoleh nilai $t$ hitung $>\mathrm{t}$ tabel atau $(7,815>2,006)$. Dengan demikian hipotesis pertama yang diajukan bahwa terdapat berpengaruh signifikan antara lingkungan kerja terhadap kinerja karyawan diterima.

Pengaruh Kompensasi Terhadap Kinerja Karyawan. Kompensasi berpengaruh signifikan terhadap kinerja karyawan dengan korelasi sebesar 0,658 atau memiliki hubungan yang kuat dengan kontribusi pengaruh sebesar 43,3\%. Pengujian hipotesis diperoleh nilai $t$ hitung $>t$ tabel atau $(6,358>2,006)$. Dengan demikian hipotesis kedua yang diajukan bahwa terdapat berpengaruh signifikan antara kompensasi terhadap kinerja karyawan diterima

Pengaruh Lingkungan kerja dan Kompensasi Terhadap Kinerja Karyawan. Lingkungan kerja dan kompensasi berpengaruh signifikan terhadap kinerja karyawan dengan diperoleh persamaan regresi $Y=8,506+0,426 X 1+0,366 X 2$, nilai korelasi sebesar 0,790 atau memiliki hubungan yang kuat dengan kontribusi pengaruh sebesar $62,4 \%$ sedangkan sisanya sebesar $37,6 \%$ dipengaruhi faktor lain. Pengujian hipotesis diperoleh nilai $\mathrm{F}$ hitung $>\mathrm{F}$ tabel atau $(43,076$ $>2,780$ ). Dengan demikian hipotesis ketiga yang diajukan bahwa terdapat berpengaruh signifikan antara lingkungan kerja dan kompensasi terhadap kinerja karyawan diterima.

\section{SIMPULAN}

Lingkungan kerja berpengaruh signifikan terhadap kinerja karyawan dengan kontribusi pengaruh sebesar 53,6\%. Uji hipotesis diperoleh nilai $t$ hitung $>t$ tabel atau $(7,815>2,006)$. Kompensasi berpengaruh signifikan terhadap kinerja karyawan dengan kontribusi pengaruh sebesar 43,3\%. Uji hipotesis diperoleh nilai $t$ hitung $>t$ tabel atau $(6,358>2,006)$. Lingkungan kerja dan kompensasi berpengaruh signifikan terhadap kinerja karyawan dengan kontribusi pengaruh sebesar $62,4 \%$ sedangkan sisanya sebesar $37,6 \%$ dipengaruhi faktor lain. Uji hipotesis diperoleh nilai F hitung $>\mathrm{F}$ tabel atau $(43,076>2,780)$.

\section{DAFTAR PUSTAKA}

Algifari. (2015). "Analisis Regresi untuk Bisnis dan Ekonomi". Yogyakarta: BPFE.

Arikunto, S (2014). "Prosedur Penelitian Suatu Pendekatan Praktek". Jakarta: Rineka Cipta. Dessler, G. (2016) Human Resources Management, Prenticehall, London: International Inc. 
Ghozali., I., (2017). “Aplikasi Analisis Multivariate Dengan Program SPSS”. Edisi Kelima. Semarang: Badan Penerbit Undip.

Griffin R.W., \& Ronald, J.E. (2003). Dasar-Dasar Pemasaran. Jakarta: Raja

Handoko, (2016) Manajemen Personalia dan Sumberdaya Manusia. Yogyakarta: BPFE.

Haryati, E., Suharyanto, A. Hasmayni, B. \& Siregar, F.H. (2019). The Effect of Work Environment and Work Stress on Employee Performance at PT Aneka Gas Industri Tbk Research Article in Proceedings of the 2nd International Conference on Social Sciences and Interdisciplinary Studies (formerly ICCSSIS), ICCSIS 2019, 24-25 October 2019, Medan, North Sumatera, Indonesia

Hasibuan, (2016) “Manajemen Sumber Daya Manusia”. Haji Masagung. Jakarta.

Istijanto, (2014) "Riset Sumber Daya Manusia”. Jakarta: PT. Gramedia Pustaka

Jasmani, J. (2019). Pengaruh Orientasi Pasar Dan Inovasi Produk Terhadap Keunggulan Bersaing Pada PT. Ragam Baja Nusantara. Disrupsi Binis, 2(1).

Jasmani, J., \& Sunarsi, D. (2020). The Influence of Product Mix, Promotion Mix and Brand Image on Consumer Purchasing Decisions of Sari Roti Products in South Tangerang. PINISI Discretion Review, 1(1), 165-174.

Latief, A. Rosalina, D. \& Apiska, D. (2019). Analisis Hubungan Antar Manusia terhadap Kinerja Karyawan. Journal of Education, Humaniora and Social Sciences (JEHSS). 1 (3): 127-131.

Latief, A. Zati, M.R. \& Pribadi, K. (2018). Analisis Faktor Faktor Yang Mempengaruhi Kinerja Karyawan. JUPIIS: Jurnal Pendidikan Ilmu-ilmu Sosial, 10 (2): 167-172.

Latief, A., Nurlina, N., Medagri, E., \& Suharyanto, A. (2019). Pengaruh Manajemen Pengetahuan, Keterampilan dan Sikap terhadap Kinerja Karyawan. JUPIIS: Jurnal Pendidikan Ilmu-Ilmu Sosial, 11(2), 173-182. doi:https://doi.org/10.24114/jupiis.v11i2.12608

Luthans, F. (2016) Organizational Behavior, McGraw-Hill, New York.

Mangkunegara, A.P, (2008). "Manajemen Sumber Daya Manusia Perusahaan, cetakan pertama”. Penerbit: Remaja Rosdakarya, Bandung

Mora, Z., Suharyanto, A., Yahya, M., (2020). Effect of Work Safety and Work Healthy Towards Employee's Productivity in PT. Sisirau Aceh Tamiang, Budapest International Research and Critics Institute, $3(2): 753-760$.

Nitisemito, A.S, (2010), Manajemen Personalia, Ghalia Indonesia, Jakarta.

Pranoto, P., Jasmani, J., \& Marayasa, I. N. (2019). Pelatihan Digital Marketing Untuk Peningkatan Perekonomian Anggota Karang Taruna Al Barkah Di Kampung Cicayur-Tangerang. Jurnal Pengabdian Dharma Laksana, 1(2), 250-258.

Purba, R, (2012). "Measuring Consumer Perceptions Through Factor Analysis”, The Asian.

Rozi, A., \& Sunarsi, D. (2020). The Influence of Motivation and Work Experience on Employee Performance at PT. Yamaha Saka Motor in South Tangerang. Jurnal Office, 5(2), 65-74.

Santoso, S. (2015). “Menguasai Statistik Multivariat”. Jakarta: PT Elex Media Komputindo.

Sedarmayanti (2016) Manajemen Sumber Daya Manusia, Reformasi Birokrasi dan Manajemen Karyawan Negeri Sipil, Cetakan Kelima, Bandung: PT Refika Aditama.

Siagian, S (2007). Manajemen Sumber Daya Manusia. Jakarta: Bumi Aksara.

Simamora, H. (2005), Manajemen Sumber Daya Manusia, STIE YKPN Bandung.

Sinamo, J. (2011). Delapan Etos Kerja Profesional. Jakarta: Institut

Sobarna, A., Hambali, S., Sutiswo, S., \& Sunarsi, D. (2020). The influence learning used ABC run exercise on the sprint capabilities. Jurnal Konseling dan Pendidikan, 8(2), 67-71.

Sudjana (2014) "Metode Statistika", Bandung: Tarsido.

Sugiyono (2017), "Metode Penelitian Administrasi : dilengkapi dengan Metode R \& D”. Bandung: Alfabeta.

Sunarsi, D. (2018). Pengembangan Sumber Daya Manusia Strategik \& Karakterisrik Sistem Pendukungnya : Sebuah Tinjauan. Jurnal Ilmiah MEA (Manajemen, Ekonomi, \& Akuntansi), 2(3), 178 - 194.

Sutrisno, E. (2016). Manajemen Sumber Daya Manusia. Jakarta: Prenadamedia Group.

Syardiansah, Latief, A., Daud, M.N., Windi, \& Suharyanto, A, (2020), The Effect of Job Satisfaction and Organizational Culture on Employee Performance of the Royal Hotel in East Aceh District, Budapest International Research and Critics Institute, 3(2): 849-857.

Triyadi, T., Ahidin, U, Jasmani (2019), Jurnal Manajemen, Bisnis dan Organisasi (JUMBO), 2019. Pengaruh Promosi Dan Kualitas Pelayanan Terhadap Kepuasan Pelanggan Pada PT. Surya Karya Prima Di Jakarta.

Veithzal, R. (2015) Manajemen Sumber Daya Manusia Untuk Perusahaan. Penerbit PT Raja Grafindo Persada, Jakarta, 2010. 
Endang Sugiarti, Pengaruh Lingkungan Kerja dan Kompensasi Terhadap Kinerja Karyawan

Yuangga, K. D., \& Sunarsi, D. (2018). The Influence of Procrastination and Low Time Management on Student Self Efficacy (at MA Soebono Mantofani). PINISI Discretion Review, 2(1), 85-92. 